\title{
Effects of protected methionine and variable energy supply on lactational responses in dairy cows fed grass silage-based diets*
}

\author{
Z.M. Kowalski ${ }^{1}$, P.M. Pisulewski ${ }^{2}$ and M. Görgülü̈ \\ The Agricultural University of Kraków, \\ ${ }^{1}$ Department of Animal Nutrition, \\ ${ }^{2}$ Department of Human Nutrition \\ Al. Mickiewicza 24/28, 30-059 Kraków, Poland \\ ${ }^{3}$ Department of Animal Science, University of Cukurova \\ 01-330 Adana, Turkey
}

(Received 8 November 2002; revised version 7 May 2003; accepted 15 July 2003)

\begin{abstract}
Twelve multiparous Holstein cows (average body weight $610 \mathrm{~kg} ; 56$ - $84 \mathrm{~d}$ after calving at the start of the trial) in their second, third or fourth lactation were assigned to two-factorial $(2 \times 2)$ arrangement of treatments, in a balanced changeover design, involving two levels of energy (adequate, AE, $100 \%$ vs low, LE, $80 \%$ of INRA requirements) and two levels of ruminally-protected DL-methionine (Smartamine ${ }^{\mathrm{TM}}$ M: 0 vs $20 \mathrm{~g} / \mathrm{d}$ ). The treatments were M0-AE, M20-AE, M0-LE and M20-LE. The calculated intestinal concentrations of lysine and methionine (\% PDI) were: 6.9 and 1.7, 6.9 and 2.1, 6.9 and 1.7, 6.9 and 2.2, respectively. The AE and LE diets contained (\% DM): grass silage 44 and 50, and concentrates 56 and 50, respectively. Low energy intake was obtained by reducing the total amount of feed offered (from $19.6 \mathrm{~kg} \mathrm{DM}$ in the AE diets to $16.2 \mathrm{~kg}$ in the LE diets). The diets provided $100 \%$ of requirements for protein digested in the small intestine (PDI). Average milk yield tended to be increased in the cows fed AE vs LE diets (averaging $27.4 \mathrm{vs} 26.5 \mathrm{~kg}$ ), but the differences were not significant. Milk fat, lactose and SNF contents did not respond to the treatments. Feeding ruminally protected methionine slightly, but significantly, increased milk protein content (2.91 vs $3.07 \%$, for M0 vs M20 diets; $\mathrm{P}<0.01$ ), with no effect on milk protein yield. Milk produced by the AE-fed cows contained significantly more casein-N $(\mathrm{P}<0.05)$ and less NPN $(\mathrm{P}<0.01)$ compared with the LE cows. Methionine supplementation resulted in significant increases in the contents in milk of total-N, protein-N, casein-N and whey-N (\%), with no effect on NPN and urea-N (\% in milk) and protein- $\mathrm{N} \%$ of total $\mathrm{N}$, casein- $\mathrm{N} \%$ of total-N. The effect of methionine on the content of nitrogen fractions in milk was more apparent in the cows fed the LE diets.
\end{abstract}

\footnotetext{
${ }^{*}$ Supported by the State Committee for Scientific Research, Grants No. P06E 01010 and P06E 00215
} 
It is concluded that supplementing dairy cows fed grass silage-based diets with ruminally-protected methionine had no effect on milk yield but resulted in apparent changes in milk composition. The reaction of cows to additional supply of absorbable methionine was particularly evident in energyunderfed cows.

KEY WORDS: dairy cow, grass silage, energy level, protected methionine, milk yield, milk composition

\section{INTRODUCTION}

Increasing the supply of amino acids to the small intestine of dairy cows by feeding ruminally-protected methionine has been shown to have beneficial effects on milk protein content and yield (Rulquin et al., 1993). More recently, these positive effects were demonstrated to occur irrespective of the energy balance (either positive or negative) of dairy cows (Rulquin and Delaby, 1997). However, in the above experiment cows were fed maize silage-based diets.

In experiments using cows fed grass silage, milk protein yield responses to postruminal supply of methionine (or methionine with lysine) were inconsistent, ranging from apparent increases (Xu et al., 1998; Younge et al., 2001) to no effects (Pisulewski and Kowalski, 1999a,b; Vanhatalo et al., 1999; Varvikko et al., 1999; Pisulewski et al., 2002). The lack of response to ruminally-protected methionine is unexpected, since theoretically grass silage-based diets are considered to be deficient in methionine absorbed in the intestine (Rulquin and Vérité, 1993). In addition, the potential interactions between the level of energy supply and milk protein yield responses to ruminally-protected methionine have not been studied in cows fed grass silage-based diets.

In this context, the objective of this study was to determine milk protein yield responses to ruminally-protected methionine in cows fed grass silage-based diets supplying adequate vs low energy.

\section{MATERIAL AND METHODS}

\section{Animals}

Twelve multiparous Holstein cows (average body weight $610 \mathrm{~kg}$; $56-84 \mathrm{~d}$ after calving at the start of the trial) in their second, third or fourth lactation were randomly assigned to the experiment. Cows were housed in a tie-stall barn. Experimental periods lasted 21 days, with 16 days of adaptation followed by 5 days of collection. 


\section{Design and treatments}

A two-factorial $(2 \times 2)$ experiment, involving twelve cows fed two levels of dietary energy (adequate, AE vs low, LE) and two levels of ruminally-protected DL-methionine (0 vs 20 g/d; Smartamine ${ }^{\mathrm{TM}}$ M, Rhône-Poulenc Animal Nutrition, Antony, France), was arranged as a balanced two-period changeover design (Gill and Magee, 1976). The treatments were: $0 \mathrm{~g} / \mathrm{d}$ of protected methionine and adequate energy supply (M0-AE), $20 \mathrm{~g} / \mathrm{d}$ of protected methionine and adequate energy supply (M20-AE), $0 \mathrm{~g} / \mathrm{d}$ of protected methionine and low energy supply (M0-LE) and $20 \mathrm{~g} / \mathrm{d}$ of protected methionine and low energy supply (M20-LE). For more details of the experimental design see Pisulewski et al. (2002).

\section{Diet and feeding}

The diets were formulated and fed either to provide an adequate $(\sim 100 \% \mathrm{UFL}$, $1 \mathrm{UFL}=1700 \mathrm{kcal} \mathrm{NE}$ ) or low ( $\sim 80 \% \mathrm{UFL})$ amounts of energy to the cows, as required for maintenance and lactation (INRA, 1989). The composition of the feeds is presented in Table 1. The AE and LE diets contained (\% DM): grass silage 44 and 50, and concentrates 56 and 50, respectively (Table 2). Low energy intake was obtained by reducing the total amount of feed offered (from $19.6 \mathrm{~kg} \mathrm{DM}$ in the $\mathrm{AE}$ diets to $16.2 \mathrm{~kg}$ in the LE diets). At the same time, they were formulated and fed to provide $100 \%$ of the requirements for protein digested in the small intestine (PDI). This was achieved by increasing the amount of soyabean meal in the LE diet. The composition of the diets was corrected for the silage DM content, determined weekly in a forced-air oven at $60^{\circ} \mathrm{C}$ for $48 \mathrm{~h}$. Samples of feeds were taken every week for chemical analysis. Concentrations of UFL and PDI were

TABLE 1

Chemical composition of feedstuffs

\begin{tabular}{lcccc}
\hline Specification & $\begin{array}{c}\text { Grass } \\
\text { silage }\end{array}$ & Barley & $\begin{array}{c}\text { Soyabean } \\
\text { meal }\end{array}$ & $\begin{array}{c}\text { Concentrate } \\
\text { mixture }\end{array}$ \\
\hline Dry matter, \% & 20.4 & 85.3 & 88.1 & 85.4 \\
In dry matter, \% & & & & \\
$\quad$ organic matter & 85.59 & 97.26 & 93.10 & 94.39 \\
crude protein & 16.96 & 10.11 & 48.24 & 19.76 \\
ether extract & 7.82 & 1.85 & 2.46 & 2.14 \\
crude fibre & 30.51 & 4.63 & 6.64 & 4.84 \\
NDF & 60.44 & 22.25 & 15.22 & 20.99 \\
Ca & 0.51 & 0.05 & 0.23 & 0.24 \\
P & 0.34 & 0.44 & 0.61 & 0.57 \\
\hline
\end{tabular}

${ }^{1}$ contained (\% as feed): ground barley, 56.2 ; soyabean meal, 25 ; wheat bran, 15 ; dolomite, $1 ; \mathrm{NaCl}$, 0.8 ; dicalcium phosphate, 2 
Composition and nutritive value of the experimental diets

\begin{tabular}{lcc}
\hline \multirow{2}{*}{ Specification } & \multicolumn{2}{c}{ Energy supply } \\
\cline { 2 - 3 } & adequate (AE) & low (LE) \\
\hline Diet composition, kg DM & 8.5 & 8.2 \\
$\quad$ grass silage & 3.1 & 4.8 \\
barley & 0.3 & 3.0 \\
soyabean meal & 6.5 & \\
concentrate mixture & 0.2 & 0.25 \\
mineral-vitamin mixture ${ }^{1}$ & 18.6 & 16.2 \\
Total DM, kg d ${ }^{-1}$ & & \\
& & \\
In the diet, kg DM & 1.02 & 1.01 \\
$\quad$ UFL & 175 & 214 \\
CP, g & 109 & 139 \\
PDIN, g & 97 & 112 \\
PDIE, g & & \\
${ }^{1}$ commercial mineral-vitamin mixture Kuh-Gold (Sano Nowoczesne Zywienie Zwierzat sp. z o.o., \\
Poland)
\end{tabular}

based on the tabulated values of the INRA (1989) system, whereas lysine and methionine in the sum of total AA passing to the small intestine were calculated using an amino acid profiling method described by Rulquin et al. (1998). The calculated contents of digestible lysine and methionine in PDI (\%) were 6.9 and 1.7, 6.9 and 2.1, 6.9 and 1.7, and 6.9 and 2.2, for the M0-AE, M20-AE, M0-LE and M20-LE treatments, respectively.

Cows were fed individually twice daily at 5.30 and 17.30. The amino acid supplement was mixed with a small amount of wheat bran, then top-dressed, and fed to cows according to the design. Water and mineralized salt licks were available daily.

\section{Measurements and analytical procedures}

For the third week of each 21-d experimental period, the amounts of feed offered and refused were recorded daily, and their representative samples were taken for determination of DM in a forced-air oven at $80^{\circ} \mathrm{C}$ for $48 \mathrm{~h}$. Feed and ort samples (taken proportionally on the basis of refused DM) were composited to form weekly samples for each cow and ground (Cyclotec ${ }^{\text {TM}}$; Tecator, Sweden). Their chemical composition was determined according to standard AOAC procedures (1995). NDF and ADF were analysed using the methods of Goering and Van Soest (1970).

Milk yields were recorded daily at each milking, and milk samples taken during the 5-d collection periods were assayed for protein, fat and lactose content, by infrared 
analysis, using a Milkoscan 133B (Foss Electric, Denmark). Moreover, on d 3 of the sampling period samples from a.m. and p.m. milkings were composited according to yield and analysed for N fractions (total N, NPN and non-casein N) as described by Hurtaud et al. (1993). Casein $\mathrm{N}$ was calculated as the difference between total $\mathrm{N}$ and noncasein $\mathrm{N}$, and true protein $\mathrm{N}$ as the difference between total $\mathrm{N}$ and NPN. Urea in milk was determined according to Roseler et al. (1993), using the Sigma Diagnostics kit (No 535; Sigma-Aldrich, Poland).

\section{Statistical analysis}

The data obtained were analysed by ANOVA for a balanced two-period changeover design (Gill and Magee, 1976), using the general linear models procedure of SAS (1985). The model employed for statistical analysis was as follows: $Y_{i j k}=\mu+C_{i}+P_{j}+T_{k}+E_{i j k}$, where: $\mu=$ general mean, $C_{i}=$ cow effect, $P_{j}$ $=$ period effect, $\mathrm{T}_{\mathrm{k}}=$ treatment effect, and $\mathrm{E}_{\mathrm{ijk}}=$ experimental error. All data are expressed and presented throughout the text as least square means. Differences were considered to be significant at $\mathrm{P}<0.05$, unless otherwise indicated.

\section{RESULTS}

Since dry matter intake was experimentally altered and averaged 16.8 and $14.6 \mathrm{~kg} / \mathrm{d}$, for adequate (AE) and low (LE) energy diets, respectively (Table 3), the diets supplied significantly different amounts of energy $(\mathrm{P}<0.001)$ and comparable amounts of protein PDI (PDIE). Derived from calculations based on dry matter intake and 4\% FCM yield, the AE diets did not fully meet the energy requirements of the cows. However, the estimated energy balance was, on average, significantly less negative in the cows fed AE than in those fed the LE diets ( -1.7 vs -4.2 UFL, respectively; $\mathrm{P}<0.01)$. Derived as above, the average protein supply was $1620 \mathrm{~g}$ PDI and the calculated PDI deficit ranged from 80 to $90 \mathrm{~g}$ PDI (except for the M20AE diet where the protein deficit was $-29 \mathrm{~g}$ PDI). The differences between treatments in PDI (PDIE) supply and protein deficit were insignificant. There were no effects of ruminally-protected methionine on energy and protein supply. Available lysine concentrations (LysDI \% PDI; Table 3), derived using the amino acid profiling method (Rulquin et al., 1998), were similar among the treatments, whereas those of available methionine (MetDI \% PDI) were increased from (1.7 to 2.1-2.2\%) in diets supplemented with ruminallyprotected methionine.

Generally, no apparent lactational responses of dairy cows to dietary treatments were found (Table 4). Average milk yield tended to be increased in the cows fed AE vs LE diets (averaging 27.4 vs $26.5 \mathrm{~kg}$ ), but the differences were not 


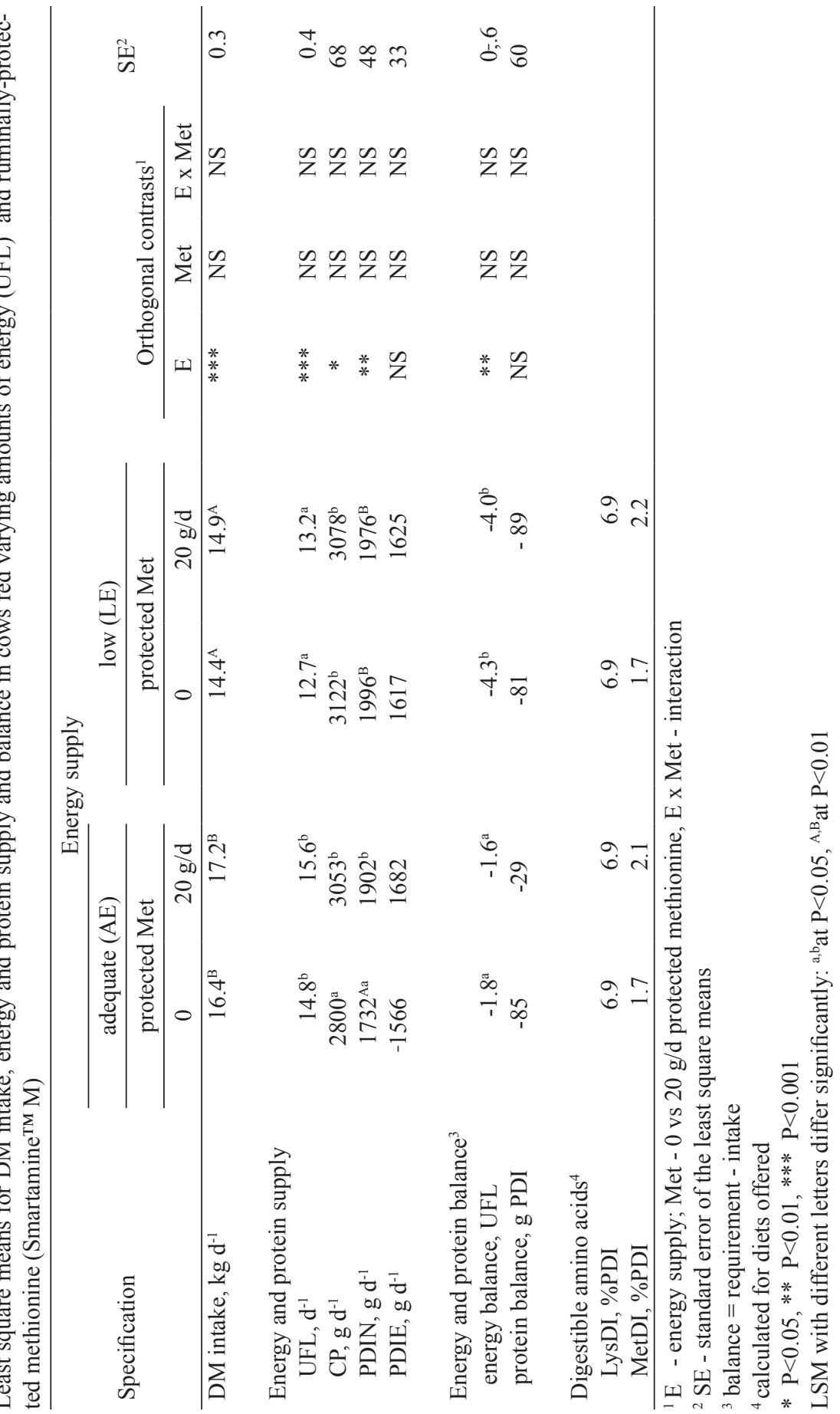


KOWALSKI Z.M. ET AL.

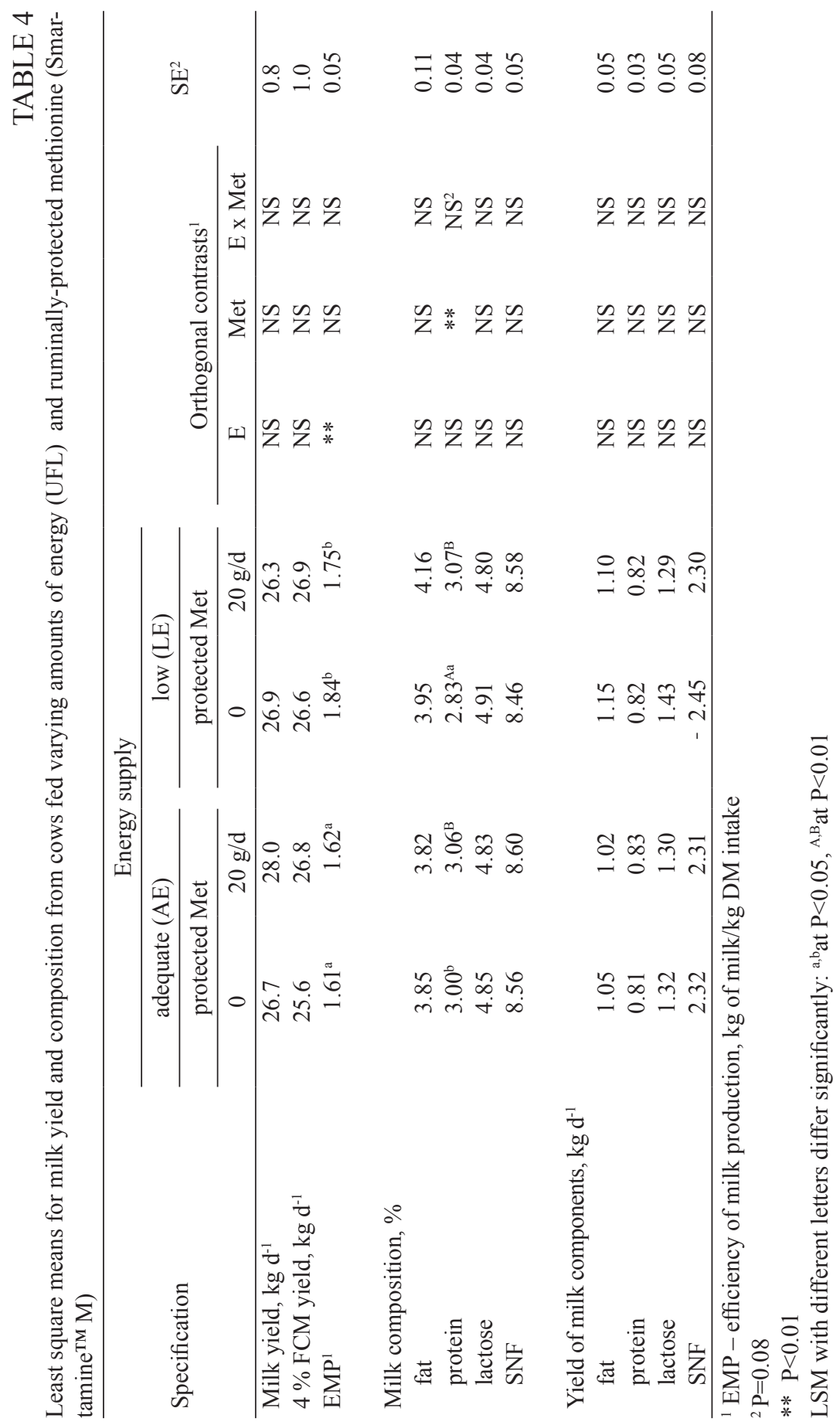




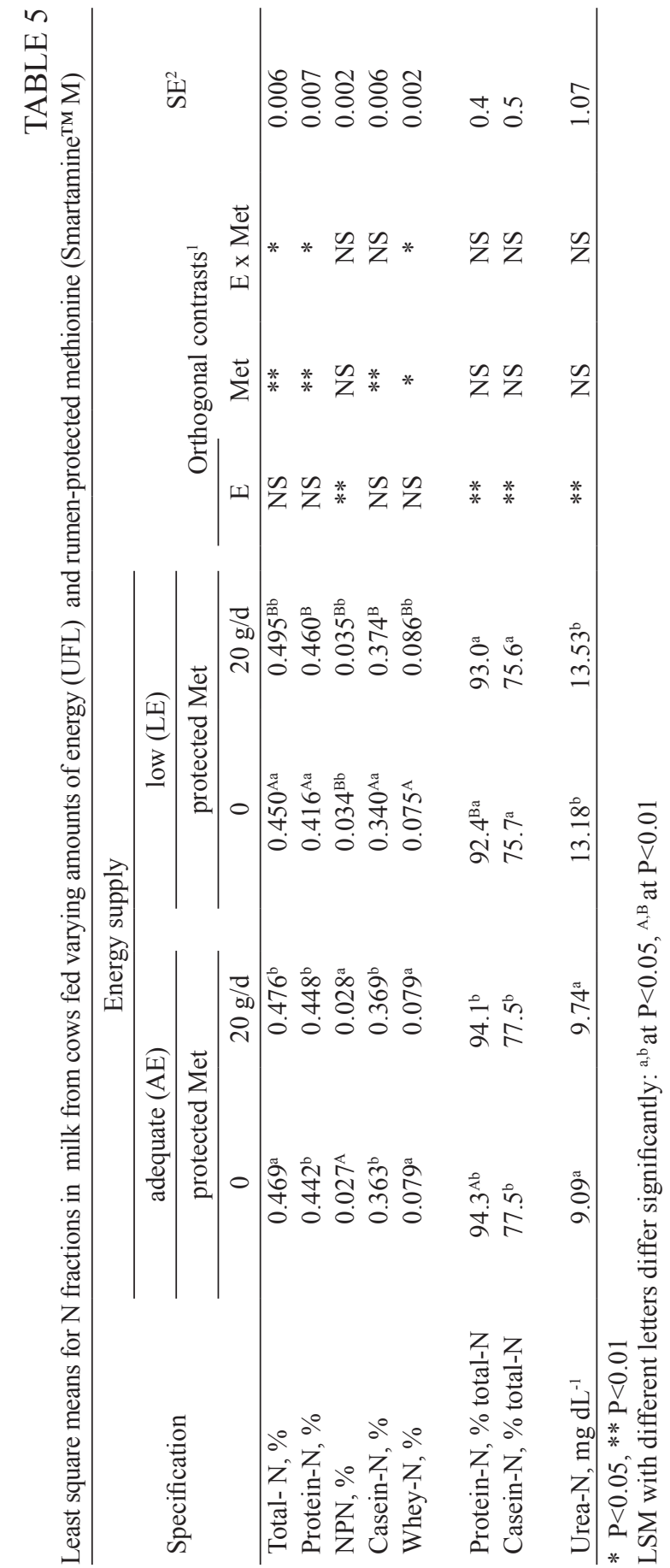


significant. On the other hand, milk in the AE- vs LE-fed cows was produced more efficiently (Effectiveness of Milk Production EMP = daily milk production ( $\mathrm{kg} / \mathrm{kgDM}$ intake); $1.61 \mathrm{vs} 1.80(\mathrm{P}<0.01)$. Milk fat, lactose and SNF content and their yield in milk did not respond to the treatments. At the same time, feeding ruminally protected methionine slightly, but significantly increased milk protein content (2.91 vs $3.07 \%$, for M0 vs M20 diets; $\mathrm{P}<0.01$ ), with no effect on milk protein yield.

Feeding restricted amounts of energy resulted in significant changes in milk nitrogen $(\mathrm{N})$ fractions (Table 5). Milk produced by the AE-fed cows contained significantly more casein-N $(\mathrm{P}<0.05)$ and less NPN $(\mathrm{P}<0.01)$. Consequently, the above changes led to significant $(\mathrm{P}<0.05)$ increases in the relative concentration of protein-N and casein-N expressed in total $\mathrm{N}$. There was also a significant effect of energy supply on milk urea nitrogen (averaging 9.41 and $13.35 \mathrm{mg} \mathrm{dL}^{-1}$, for $\mathrm{AE}$ and LE diets respectively $(\mathrm{P}<0.01)$. Methionine supplementation resulted in significant increases in the contents $(\%)$ of total-N, protein- $\mathrm{N}$, casein- $\mathrm{N}$ and whey$\mathrm{N}$, with no effect on NPN, urea-N and protein-N \% total $\mathrm{N}$, casein-N \% total-N and (Table 5). However, it was evident that the effect of methionine on nitrogen fractions in milk was more apparent in the cows fed the LE diets, as indicated by significant $(\mathrm{P}<0.05)$ interactions between energy intake and supplemental ruminally-protected methionine.

\section{DISCUSSION}

The objective of the present study was to describe the lactational responses in lactating dairy cows fed grass-silage-based diets. The diets were formulated to provide adequate or low amounts of energy (see: INRA, 1989), without or with ruminally-protected methionine supplementation (Smartamine ${ }^{\mathrm{TM}}$ M:0 vs $20 \mathrm{~g} / \mathrm{d}$ ).

According to the experimental design, low dry matter intake in the cows fed LE vs AE diets resulted in a significantly lower energy supply (Table 3). The energy intake in the cows fed AE diets did not, however, fully cover the INRA (1989) requirements. The reason could be low palatability of grass silage containing a relatively high level of NDF. On the other hand, the diets supplied similar amounts of PDI (PDIE), although slightly below the requirement. Dry matter (and energy) intake was unaffected by protected amino acid supplementation, which agrees with earlier results in cows fed grass-silage-based diets (Robert et al., 1994; Pisulewski and Kowalski, 1999a,b; Younge et al., 2001; Pisulewski et al., 2002). Similarly, postruminal (abomasal) infusions of lysine or methionine did not affect the above measurements (Varvikko et al., 1999). The concentrations of absorbable Lys and Met in total absorbable amino acids (PDI) were calculated as described by Rulquin et al. (1998). Absorbable Lys concentrations, averaging 6.9\% PDI, were identical 
across the treatments and only slightly below the optimum value of $7.30 \%$ PDI, established by Rulquin et al. (1993). At the same time, the low concentrations of absorbable methionine in the M0 diets were largely increased by the supplementation of ruminally-protected methionine (M20), but still, they did not reach the optimum concentration of 2.50 MetDI \% PDI (Rulquin et al., 1993).

The cows fed AE diets tended to have a higher milk yield than the cows fed LE diets (Table 4), although more pronounced differences could have been expected. The reason could be a too short experimental period. Moreover, the cows were in the first 100 days of lactation, when some part of the energy requirements could have been covered by mobilization of body reserves (Goff and Horst, 1997). Unfortunately, neither changes in liveweight nor in body condition were measured in this short study period.

The lack of milk yield responses to ruminally-protected methionine is in line with the results of others (Robert at al., 1994; Pisulewski and Kowalski, 1999a,b; Younge et al., 2001; Pisulewski et al., 2002). Milk yield was equally unaffected by postruminal infusions of lysine or methionine (Varvikko et al., 1999). The only exception is the report indicating that in early lactation, protected lysine and methionine supplements increased milk yield in cows fed grass-silage-based diets (Xu et al., 1998).

The variable energy intake did not significantly affect milk composition (Table 4). The commonly known effect of energy deficit is a decrease in milk protein content (Coulon and Remond, 1991; DePeters and Cant, 1992; Colin-Schoellen et al., 1995; Dewhurst et al., 1999). Accordingly, in the present study we observed a tendency towards lower protein content in the milk produced by cows fed LE diets (3.03 and $2.95 \%$, for AE and LE diets, respectively). There was also a tendency towards lower fat content in milk from the cows fed AE diets, which also agrees with the previous studies (e.g., Coulon and Remond, 1991; Colin-Schoellen et al., 1995).

Except for milk protein content, there was no effect of ruminally-protected methionine on milk composition (Table 4). Moreover, the positive effect of methionine on milk protein concentration was significant and more apparent in the cows fed LE diets. In comparable experiments, mainly when maize silage was the basal forage, feeding protected amino acids (lysine, methionine or both) also increased milk protein content (Rulquin, 1992; Robert et al., 1994; Rulquin et al., 1994; Chillard et al., 1995; Xu et al., 1998; Younge et al., 2001). However, in some other trials, using grass silage as the basal forage, milk protein concentration responses to protected methionine, as the only supplemental amino acid, were less convincing or nonexistent (Pisulewski and Kowalski, 1999b; Younge et al., 2001; Pisulewski et al., 2002). At the same time, neither lysine nor methionine were limiting for milk protein concentration in cows offered a grass silage-based diet (Vanhatalo et al., 1999; Varvikko et al., 1999). According to the Finish group (Vanhatalo et al., 1999; Huhtanen et al., 2002), histidine is the first limiting amino acid for dairy cows fed 
on grass silage diets, and methionine or lysine are not even second-limiting. Based on the above-quoted results, it might be concluded that the effect of postruminal methionine (and other AA) supply on milk protein content depends on the basal diet. Thus, the basal diet may determine which amino acid is first limiting.

It is worth noting that the interaction of energy supply $\mathrm{x}$ methionine supplementation on milk protein content was almost significant $(\mathrm{P}=0.08$; Table 4$)$. It shows that the reaction of cows on supplemental methionine was more apparent in the energy-underfed cows, which is in line with the results of Colin-Schoellen et al. (1995). The cows fed M0-LE diets produced milk with the lowest protein content. On the other hand, Rulquin and Delaby (1997) showed that ruminallyprotected methionine can be used with diets based on maize silage to increase the protein content of milk, even for cows being in a negative energy balance.

Neither energy intake nor ruminally-protected methionine affected the yield of milk components, thus reflecting no effect on milk yield and composition. In contrast to our findings, feeding ruminally-protected lysine, methionine or both (associated with increased milk protein content) usually brings improvements in milk protein yield (Rulquin, 1992; Robert et al., 1994; Rulquin et al., 1994; Chillard et al., 1995; Pisulewski et al., 1996). However, more recently, this effect was not observed by Varvikko et al. (1999) and Pisulewski et al. (2002).

As expected, energy supply influenced milk N fractions (Table 5). Significant increase in NPN and urea concentrations and significant decrease in casein-N were anticipated as resulting from restricted energy supply. Also total-N in milk from the cows fed LE diets contained less protein-N and casein-N. Similar increases in milk NPN and decreases in protein-N in milk of the cows fed low-energy diets were observed by Colin-Schoellen et al. (1995).

Feeding ruminally-protected methionine (Table 5) increased total-N, protein$\mathrm{N}$, casein- $\mathrm{N}$, and had no effect on protein- $\mathrm{N}$ and casein-N content in total-N. This is in line with the results of several studies (Rulquin, 1992; Christensen et al., 1994; Robert et al., 1994; Xu et al., 1998; Younge et al., 2001). Therefore, it seems probable that methionine was limiting for synthesis of milk protein. This is in contrast to our earlier studies where the above effects were not demonstrated (Pisulewski and Kowalski, 1999a,b; Pisulewski et al., 2002). Such equivocal responses are difficult to explain. On the other hand, neither lysine nor methionine increased the casein fraction in milk from cows fed the grass silage-based diet (Varvikko et al., 1999). The effect of ruminally-protected methionine on total-N and protein-N was more apparent in the cows fed LE, as indicated by significant interactions $(\mathrm{P}<0.05)$. It is possible that the additional supply of methionine compensated its deficit resulting from lower microbial protein (amino acids) supply in the cows fed LE diets.

In conclusion, supplementing dairy cows fed grass silage-based diets with ruminally-protected methionine, had no effect on milk yield. In contrast, it 
resulted in apparent changes in milk composition. The effect of additional supply of absorbable methionine on milk composition was more evident in energyunderfed cows.

\section{ACKNOWLEDGEMENT}

The authors wish to thank Mrs. Alina Marszałek for chemical analyses and the staff of the dairy farm at the Lipowa Experimental Station (Research Institute of Animal Production, Poland) for the care and feeding of cows.

\section{REFERENCES}

AOAC, 1995. Association of Official Analytical Chemists, Official Methods of Analysis. 16th Edition. Arlington, VA

Chillard Y., Rouel J., Ollier A., Bony J., Tanan K., Sloan B.K., 1995. Limitations in digestible methionine in the intestine (MetDI) for milk protein secretion in dairy cows fed a ration based on grass silage. Anim. Sci. 60, 553 (Abstr.)

Christensen R.A., Cameron M.R., Clark J.H., Drackley J.K., 1994. Effects of amount of protein and ruminally protected amino acids in the diet of dairy cows fed suupplemental fat. J. Dairy Sci. 77, 1619-1629

Colin-Schoellen O., Laurent F., Vignon B., Robert J.C., Sloan B., 1995. Interactions of ruminally protected methionine and lysine with protein source or energy level in the diets of cows. J. Dairy Sci. 78, 2807-2818

Coulon J.B., Remond B., 1991. Variations in milk output and milk protein content in response to the level of energy supply to the dairy cow: a review. Livest. Prod. Sci. 29, 31-47

DePeters E.J., Cant J.P., 1992. Nutritional factors influencing the nitrogen composition of bovine milk: a review. J. Dairy Sci. 75, 2044-2069

Dewhurst R.J., Aston K., Fisher W.J., Evans R.T., Dhanoa M.S., McAllan A.B., 1999. Comparison of energy and protein sources offered at low levels in grass-silage-based diets for dairy cows. Anim. Sci. 68, 789-799

Gill J.L., Magee W.T., 1976. Balanced two-period change-over designs for several treatments. J. Anim. Sci. 42, 775-777

Goering H.K., Van Soest P.J., 1970. Forage Fiber Analyses (Apparatus, Reagents, Procedures, and Some Applications). Agric. Handbook No. 379. ARS-USDA. Washington, DC

Goff J.P., Horst R.L., 1997. Physiological changes at parturation and their relationship to metabolic disorders. J. Dairy Sci. 80, 1260-1268

Huhtanen P., Vanhatalo A., Varvikko T., 2002. Effects of abomasal infusions of histidine, glucose, and leucine on milk production and plasma metabolites of dairy cows fed grass silage diets. J. Dairy Sci. 85, 204-216

Hurtaud C., Rulquin H., Vérité R., 1993. Effect of infused volatile fatty acids and caseinate on milk composition and coagulation in dairy cows. J. Dairy Sci. 76, 3011-3020

INRA, 1989. R. Jarrige (Editor). Ruminant Nutrition: Recommended Allowances and Feed Tables. John Libbey Eurotext, London 
Pisulewski P.M., Kowalski Z.M., 1999a. The effect of protected lysine and methionine on milk yield and its composition in lactating dairy cows fed grass silage-based diets. J. Anim. Feed Sci. 8, 341-353

Pisulewski P.M., Kowalski Z.M., 1999b. The effect of protected methionine on milk yield and its composition in lactating dairy cows fed grass silage-based diets. J. Anim. Feed Sci. 8, 355-366

Pisulewski P.M., Kowalski Z.M., Görgülü M., 2002. Lactational responses to ruminally-protected methionine in cows fed a low-protein grass silage-based diet. J. Anim. Feed Sci. 11, 189-203

Pisulewski P.M., Rulquin H., Peyraud J.L., Vérité R., 1996. Lactational and systemic responses of dairy cows to postruminal infusions of increasing amounts of methionine. J. Dairy Sci. 79, 1781-1791

Robert J.C., Sloan B.K., Denis C., 1994. The effect of protected amino acid supplementation on the performance of dairy cows receiving grass silage plus soya-bean meal. Anim. Prod. 58, 437 (Abstr.)

Roseler D.K., Ferguson J.D., Sniffen C.J., Herrema J., 1993. Dietary protein degradability effects on plasma and milk urea nitrogen and milk nonprotein nitrogen in Holstein cows. J. Dairy Sci. 76, 525-534

Rulquin H., 1992. Intérêts et limites d'un apport de méthionine et de lysine dans l'alimentation des vaches laitieres. INRA Prod. Anim. 5, 29-36

Rulquin H., Delaby L., 1997. Effects of the energy balance of dairy cows on lactational responses to rumen-protected methionine. J. Dairy Sci. 80, 2513-2522

Rulquin H., Guinard J, Vérité R., 1998. Variation of amino acid content in the small intestine digesta: development of a prediction model. Livest. Prod. Sci. 53, 1-13

Rulquin H., Hurtaud C., Delaby L., 1994. Effects of dietary protein level on lactational responses of dairy cows to rumen-protected methionine and lysine. Ann. Zootech. 43, 245 (Abstr.)

Rulquin H., Pisulewski P.M., Vérité R., Guinard J., 1993. Milk production and composition as a function of postruminal lysine and methionine supply: a nutrient-response approach. Livest. Prod. Sci. 37, 69-90

Rulquin H., Vérité R., 1993. Amino acid nutrition of dairy cows: productive effects and animal requirements. In: P.C. Garnsworthy, D.J.A. Cole (Editors). Recent Advances in Animal Nutrition. Nottingham University Press, Nottingham, pp. 55-77

SAS Institute Inc., 1985. SAS/STAT ${ }^{\mathrm{TM}}$. Guide for Personal Computers, Version 6. Carry, NC, SAS Institute, Inc.

Vanhatalo A., Huhtanen P., Toivonen V., Varvikko T., 1999. Response of dairy cows fed grass silage diets to abomasal infusions of histidine alone or in combinations with methionine and lysine. J. Dairy Sci. 82, 2674-2685

Varvikko T., Vanhatalo A., Jalava T., Huhtanen P., 1999. Lactation and metabolic responses to graded abomasal doses of methionine and lysine in cows fed grass silage diets. J. Dairy Sci. 82, 26592673

Xu S., Harrison J.H., Chalupa W., Sniffen C., Julien W., Sato H., Fujieda T., Watanabe K., Ueda T., Suzuki H., 1998. The effect of ruminal bypass lysine and methionine on milk yield and composition of lactating cows. J. Dairy Sci. 81, 1062-1077

Younge B.A., Murphy J.J., Rath M., Sloan B.K., 2001. Effect of dietary absorbable methionine and lysine concentrations on milk production and composition of dairy cows offered grass-silage based diets. Irish J. Agr. Food Res. 40, 1-11 


\section{STRESZCZENIE}

\section{Wpływ chronionej metioniny oraz podaży energii na wydajność i skład mleka krów żywionych dawką pokarmową z udziałem kiszonki z traw}

Doświadczenie przeprowadzono na 12 krowach wieloródkach rasy holsztyńsko-fryzyjskiej (średnia masa ciała $610 \mathrm{~kg}$; 56-84 dzień laktacji na początku doświadczenia), w 2, 3 i 4 laktacji, w dwuczynnikowym ( 2 x 2) układzie przemiennym. Zwierzęta żywiono dawkami pokarmowymi zapewniającymi zróżnicowaną podaż energii (AE - 100\% lub LE - 80\% zapotrzebowania wg INRA), podawanymi bez dodatku lub z dodatkiem chronionej syntetycznej DL-metioniny (Smartamine ${ }^{\mathrm{TM}} \mathrm{M}$ : M0-0 lub M20 - 20 g/d). W każdej z kombinacji czynników doświadczalnych, tj. M0-AE, M20-AE, M0-LE i M20-LE, obserwacji poddano 6 krów. Dawki pokarmowe AE i LE zawierały odpowiednio (\% s.m.): kiszonkę z traw - 44 i 50 i mieszankę pasz treściwych - 56 i 50. Niskie pobranie energii (dawki LE) zapewniono przez zmniejszenie ilości pasz zadawanych krowom (AE - 19,6 i LE - 16,2 kg s.m./dzień). Dawki w pełni pokrywały zapotrzebowanie na BTJ. Obliczone stężenia jelitowe lizyny i metioniny (\% BTJ) w dawkach doświadczalnych wynosiły 6,9 i 1,7,6,9 i 2,1, 6,9 i 1,7 oraz 6,9 i 2,2, odpowiednio dla dawek M0-AE, M20-AE, M0-LE i M20-LE.

Stwierdzono tendencję do wyższej wydajności mleka u krów żywionych dawkami AE w porównaniu z krowami żywionymi dawkami LE (średnio 27,4 i 26,5 kg/dzień), jednak różnice okazały się statystycznie nieistotne. Czynniki doświadczenia nie miały wpływu na zawartości w mleku tłuszczu, laktozy i suchej masy beztłuszczowej. Dodatek chronionej metioniny spowodował nieznaczne, ale statystycznie istotne zwiększenie zawartości białka w mleku (2,91 i 3,07\%, odpowiednio dla dawek M0 i M20; $><0,01)$, lecz nie miał wpływu na wydajność białka mleka. Mleko produkowane przez krowy żywione dawkami AE zawierało statystycznie istotnie więcej $\mathrm{N}$-kazeinowego $(\mathrm{P}<0,05)$ i mniej NPN $(\mathrm{P}<0,01)$. Dodatek metioniny istotnie zwiększył zawartość N-ogólnego, N-białkowego, N-kazeinowego i N-serwatkowego w mleku (\%), lecz nie miał wpływu na zawartość NPN, N-mocznika oraz na udział N-białkowego i N-kazeinowego w N-ogólnym. Wpływ metioniny na zawartość frakcji azotowych w mleku był wyraźniejszy u krów żywionych dawkami LE.

Uzupełnianie chronioną metioniną dawek pokarmowych dla krów mlecznych żywionych kiszonką z traw, jako paszą podstawową, nie miało wpływu na wydajność mleka. Powodowało jednak istotne zwiększenie zawartości białka w mleku oraz korzystne zmiany w zawartości frakcji azotowych. Tendencje te były wyraźniejsze u krów otrzymujących dawki niedoborowe pod względem energii. 